\title{
Statyba
}

\section{INFLUENCE OF ADDITIVES AND SULPHUROUS MAZOUT ON THE QUALITY OF CARBONACEOUS CLINKERY CERAMIC SPLINTER}

\section{A. Kaminskas , G. Smolianskienė \& Č. Valiukevičius}

To cite this article: A. Kaminskas, G. Smolianskienè \& Č. Valiukevičius (1999) INFLUENCE OF ADDITIVES AND SULPHUROUS MAZOUT ON THE QUALITY OF CARBONACEOUS CLINKERY CERAMIC SPLINTER, Statyba, 5:5, 323-328, DOI: 10.1080/13921525.1999.10531483

To link to this article: https://doi.org/10.1080/13921525.1999.10531483

Published online: 26 Jul 2012.

Submit your article to this journal $\llbracket$

Щ Article views: 70

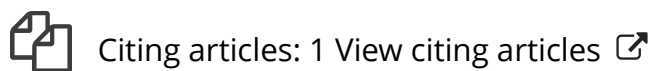




\title{
SUKEPIMĄ SKATINANČIŲ PRIEDŲ IR SIERINGO MAZUTO ITAKA KARBONATINGO MOLIO KERAMINĖS ŠUKĖS KOKYBEI
}

\author{
A. Kaminskas, G. Smolianskienė, Č. Valiukevičius
}

\section{Ivadas}

Keraminèms klinkerinèms plytoms keliami reikalavimai reglamentuojami ES šalių standartu, kuriuose nurodoma, kad gaminių vandens imirkis turi būti $<6 \%$, keraminès šukès tankis $\geq 2,0 \mathrm{~kg} / \mathrm{dm}^{3}$, stipris gniuždant $\geq 40 \mathrm{MPa}$. Aukštos kokybès klinkerinił plytu gamybai naudojami sunkiai besilydantys, sukepantys moliai, plytos degamos neturinčiomis sieros gamtinèmis dujomis. Mūsu šalyje keramikos gamyklos turi technologinę irangą lengvai besilydantiems karbonatingiems moliams perdirbti ir išdegti, tačiau tokios kokybès, kai vandens imirkis $<6 \%$, keramikos gaminiams gauti ji nepritaikyta. Lietuvos Respublikoje nèra norminio dokumento klinkerinių plytu gamybai. Standarte (LST 1458) klinkerinès ir sukepusios plytos apibrěžiamos tik kaip gaminiai, kuriu vandens imirkis atitinkamai mažesnis kaip $6 \%$ ir $5 \%$.

Pastaraisiais metais pasaulinèje rinkoje labai sumažejo naftos ir jos produktu kainos. Kadangi klinkerinių plytų gamybai kuro sunaudojama gerokai daugiau, negu degant statybines plytas, ekonomiškiau būtų naudoti ne gamtines dujas, bet mazuta. Jis kaloringesnis už gamtines dujas (atitinkamai $39775 \mathrm{~kJ} / \mathrm{kg}$ ir $33494 \mathrm{~kJ} / \mathrm{kg}$ ), todèl skaiciuojant kuro poreiki reikia taikyti koeficientą 39775:33494=1,19. Mazuto vienos tonos vidutinè metine kaina yra $240 \mathrm{Lt}$, o vieno $\mathrm{n} . \mathrm{m}^{3}$ duju -- $320 \mathrm{Lt}$. Ivertinę ju kaloringumo skirtumą gautume, kad kürenant dujomis kuras kainuotu $-320 \times 1,19=380,8$ Lt n. ${ }^{3}$, t. y. net 140,8 Lt daugiau. Tačiau mazutas savo sudetyje turi 2,5$3,5 \%$ sieros. Dèl to fasadinių klinkeriniu plytų paviršiuje atsiranda sulfatiniu demiu kurios blogina gaminiu prekinę išvaizdą. Šiame darbe tirtos galimybès gauti klinkerinę keramiką iš Kertupis-2 telkinio karbonatingo lengvai besilydančio molio, parenkant sukepimą skatinančius priedus, ir nustatyti sieringo mazuto itaką keraminès šukès savybems.
Koreguojant formavimo mišinius "Centrolito" smèlio, šamoto, durpių, antracito, dolomito, malto stiklo, marmuro šlifavimo atlieku priedais bei imaišant Dysnos, Ukmergès, Rašnavos molių, buvo siekiama pagerinti tik akytosios keramikos gaminiu kokybę $[1,2]$. Formavimo masių sukepimo procesu kinetika bei galimybès gauti sukepusios keramikos dirbinius (kai gaminiu imirkis $<6 \%$ ) anksčiau nebuvo tyrinètos.

Mikrogranuliometrinès analizès duomenys (Vinklerio trifaze diagrama) patvirtina, kad ši karbonatinga moli reikia priskirti žaliavoms, tinkamoms tik statybinių plytu, čerpių ir plonasieniu dirbinių gamybai. Tačiau aukštas Kertupio molio dispersiškumo lygis leidžia tikètis, kad, koreguojant gaminiu formavimo masès sudèti atitinkamais sukepimą skatinančiais priedais, galima gauti ir sukepusios keramikos gaminius.

\section{Tyrimų metodika ir žaliavos}

Darbe ištyrus Kertupio-2 molio telkinio du èminius, kuriu cheminè sudetis pateikta 1 lenteleje, tolesniems tyrimams buvo panaudotas antrojo èminio molis. Palyginti su pirmojo èminio moliu, jis yra mažiau karbonatingas, nes žemès šarminių metalų oksidu ( $\mathrm{CaO}$ ir $\mathrm{MgO})$ kiekis jame sudaro $11,37 \%$. Rentgenografiniu metodu ištirta šio molio mineraloginè sudètis.

Rentgenografinè analizé atlikta difraktometru DRON-2 (Rusija) su $\mathrm{Cu}$ antikatodu ir $\mathrm{Ni}$ filtru, kai $\mathrm{U}=30 \mathrm{kV}, \mathrm{I}_{\mathrm{a}}=8 \mathrm{~mA}$ ir bandinio sukimo greitis $1^{\circ} \mathrm{min}^{-1}$. Rentgenogramos užregistruotos popieriuje savirašiu ir iššifruotos, lyginant su duomenimis ASTM kartotekoje bei mokslineje literatūroje [3]. Remiantis 1 pav. pateiktos rentgenogramos duomenimis, nustatyta, kad Kertupio-2 molyje pagrindiniai mineralai yra ilitas (hidrožèrutis) $(\mathrm{O})$, kaolinitas (Ka); ne molio mineralai - feldšpatai $(F)$, kvarcas (Q), kalcitas (K), dolomitas (D). Kiti rentgenogramose 
1 lentelè. Laboratoriniams tyrimamas naudoto Kertupio-2 molio eminių cheminè sudetis

Table 1. Chemical composition of Kertupis-2 clays for laboratorial experiment

\begin{tabular}{|c|c|c|c|c|c|c|c|c|}
\hline \multirow{2}{*}{ Éminio Nr. } & \multicolumn{8}{|c|}{ Cheminè sudètis, \% } \\
\hline & $\mathrm{SiO}_{2}$ & $\mathrm{Al}_{2} \mathrm{O}_{3}$ & $\mathrm{Fe}_{2} \mathrm{O}_{3}$ & $\mathrm{CaO}$ & $\mathrm{MgO}$ & $\mathrm{SO}_{3}$ & $\mathrm{CO}_{2}$ & K.n. $\quad *$ \\
\hline l (1998 0204$)$ & 48,20 & 16,69 & 6,39 & 9,83 & 4,60 & 0,50 & 6,59 & 13,02 \\
\hline $2(19980306)$ & 47,46 & 20,52 & 8,15 & 7,20 & 4,17 & 0,32 & 3,04 & 11,25 \\
\hline
\end{tabular}

${ }^{*}$ Kaitinimo nuostoliaj $1000{ }^{\circ} \mathrm{C}$

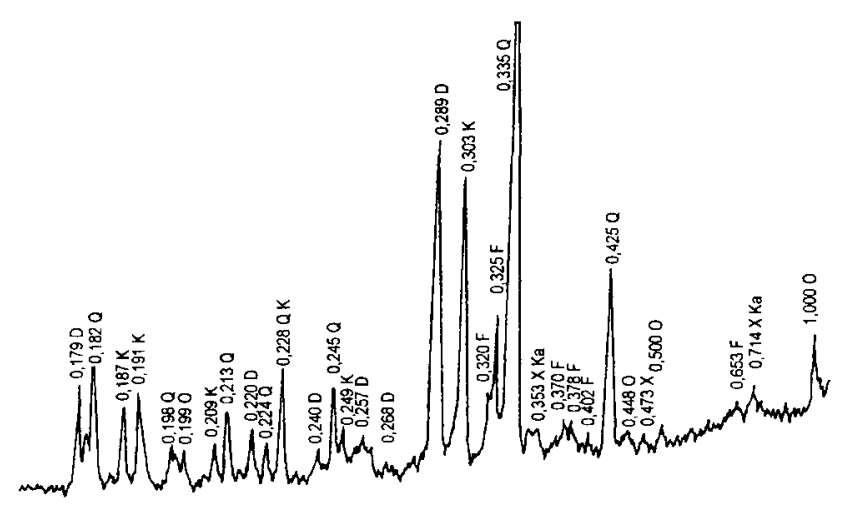

1 pav. Ketupio-2 molio rentgenograma (nm)

Fig 1. XRD pattern of Kertupis-2 clay (nm)

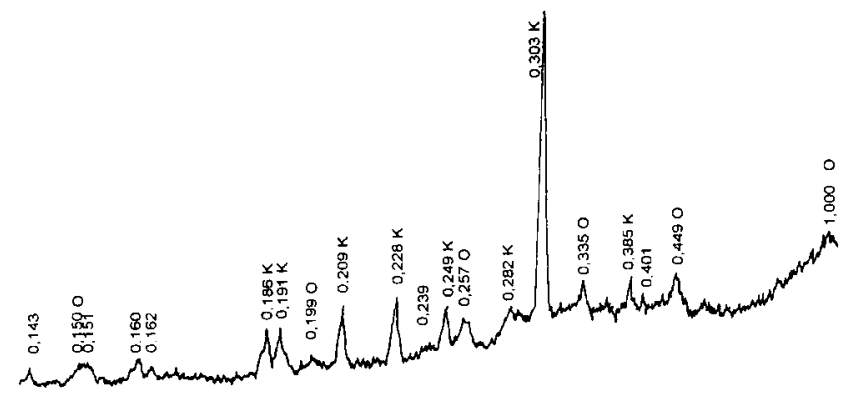

2 pav. Kertupio-2 molio vandeninès ištraukos sausos liekanos rentgenograma $(\mathrm{nm})$

Fig 2. XRD pattern (nm) of dry remnant Kertupis-2 clay watery extract

vartojami trumpiniai reiškia: A (anortitas), An (anhidritas), Di (diopsidas), $\mathrm{H}$ (hematitas).

Ištyrus ivvairių molio frakcijų sudèti nustatyta, kad molingoje frakcijoje yra $60 \%$ hidrožèručio, $20 \%$ kaolinito ir $20 \%$ montmorilonito.

Vandenineje Kertupio-2 molio ištraukoje vyrauja kalcio hidrokarbonatas $\left(\mathrm{Ca}\left(\mathrm{HCO}_{3}\right)_{2}\right)$, ir, garinant tirpala, susidaro kalcio karbonatas $\left(\mathrm{CaCO}_{3}\right)$. Todèl sausos liekanos rentgenogramoje išryškejja kalcito smailès $(0,303$; $0,249 ; 0,228 ; 0,209 ; 0,191 ; 0,186) \mathrm{nm}(2$ pav.).
Kertupio-2 molio pagrindu paruoštų formavimo mišinių su ịvairiais priedais sudètys pateiktos 2 lenteleje.

Ruošiant formavimo mišinius, visi komponentai prieš dozavimą buvo džiovinami $100-110^{\circ} \mathrm{C}$ temperatūroje, sumalami ir sijojami per sietą $\mathrm{Nr} .1$.

Dilatometriniai tyrimai [4] buvo atliekami dilatometru DKV (Rusija).

Cilindrinès formos bandiniai iš modelinių formavimo mišinių buvo presuojami rankiniu būdu (preso galvutès skersmuo $10 \mathrm{~mm}$ ). Kambario temperatūroje išdžiovinti bandiniai buvo degami dilatometre iki $1000^{\circ} \mathrm{C}$ oksidacinèje aplinkoje. Temperatūros kélimo greitis ne didesnis kaip $4^{\circ} \mathrm{C}$ min-1. Kas $10 \mathrm{~min}$ bandinio ilgio pokytis buvo fiksuojamas ilgio matavimo indikatoriumi $0,001 \mathrm{~mm}$ tikslumu.

Sieringiems junginiams nustatyti cheminès analizès metodu [5] buvo paruošti ir mazutu kūrenamoje krosnyje išdegti $\mathrm{AB}$ „Palemono keramika“ gamybiniai bandiniai. Formavimo mišinys buvo sudarytas iš Kertupio-2 molio su priedais ( $10 \%$ smelio, $5 \%$ šamoto, $2-3 \%$ pjuvenu ir $0,2 \%$ bario karbonato).

2 lentelè. Formavimo mišinių sudetys

Table 2. Composition of forming mixtures

\begin{tabular}{|c|c|l|}
\hline \multirow{2}{*}{$\begin{array}{c}\text { Bandinio } \\
\text { Nr. }\end{array}$} & \multicolumn{2}{|c|}{ Formavimo mišinių sudètys } \\
\cline { 2 - 3 } & $\begin{array}{c}\text { Kertupis-2 } \\
\text { molis, \% }\end{array}$ & \multicolumn{1}{|c|}{ Priedai, \% (masès) } \\
\hline 1 & 70 & Ukmergès molis, 30 \\
\hline 2 & 90 & Langu stiklo laužas, 10 \\
\hline 3 & 85 & Langu stiklo laužas, 15 \\
\hline 4 & 80 & Langų stiklo laužas, 20 \\
\hline 5 & 90 & Mikrosilicis, 10 \\
\hline 6 & 85 & Mikrosilicis, 15 \\
\hline 7 & 80 & Mikrosilicis, 20 \\
\hline 8 & 79 & Glaukonitas, 20; anglis, 1 \\
\hline 9 & 95 & Kreida, 5 \\
\hline 10 & 90 & Kreida, 10 \\
\hline
\end{tabular}


Dujų emisijos i atmosferą ir dulkių kiekio dūmuose matavimai atlikti „Lietuvos elektrineje“ (Elektrènuose), deginant orimulsiją ir mazutą M100 [6] po $24 \mathrm{t} / \mathrm{h}$. Matavimai atlikti prieš filtrą ir po filtro. Dulkèms paimti naudota sistema Emcs-3866. Dujų analizatoriumi TESTO-33 išmatuotos $\mathrm{SO}_{2}, \mathrm{No}_{\mathrm{x}}, \mathrm{CO}_{2}$ duju koncentracijos. Palyginimui buvo paruoštas mišinys iš mazuto M100 ir gaudyklinès naftos santykiu 9:2, emulguotas su magnio oksido priedu $[7,8]$ ir sudegintas $A B$,Mažeikiu nafta“ garo ceche (kuro sąnaudos $-1 \mathrm{t} / \mathrm{h}$ ).

\section{Darbo rezultatai ir jų aptarimas}

Skirtingos sudeties bandiniu formavimo drègmes ir sukepimo lygio ivertinimo rodikliai priklausomai nuo išdegimo temperatūros pateikti 3 lentelèje. Tarp šių rodiklių matomas koreliacinis ryšys: mažèjant medžiagos vandens imirkiui, dideja keraminès šukès tankis ir bandinių degamasis susitraukimas. Priedų itaka gryno Kertupio-2 molio sukepimui atitinka dilatometriniu tyrimu rezultatus, kurie rodo staigius ilgio pokyčius sukepimo metu. Degant iki $1000^{\circ} \mathrm{C}$, visu laboratorinių bandiniu vandens įmirkio rodiklis viršija $10 \%$. Pakèlus degimo temperatūra $30^{\circ} \mathrm{C}$, bandiniu su $10 \%$ stiklo laužo, Ukmergès molio $30 \%$ ir glaukonito $20 \%$ priedais vandens imirkis mažèja nežymiai. Didejjant stiklo laužo ir ypač mikrosilicio kiekiui, priedo itaka medžiagos sukepimui dideja. Šių bandiniu vandens imirkis svyruoja nuo 0,4 iki $8,1 \%$. Esant maksimaliai degimo temperatūrai $1050^{\circ} \mathrm{C}$, visų sudėčių bandiniai, išskyrus mišinių su $10 \%$ stiklo laužo priedu, sukepa iki vandens imirkio 0,5-6,8\%. Bandinių su mikrosilicio priedu vandens imirkis mažiausias - 0,5$1,1 \%$, tačiau matyti deformacijos požymiai.

Laboratorinių bandinių Nr. 1-10 dilatometrinès kreivès charakteringos karbonatiniams moliams (36 pav.). Bandiniu terminio išsipletimo intensyvumo padidejimas $550^{\circ} \mathrm{C}$ temperatūroje priklauso nuo kvarco tūrio kitimo pereinant iš $\beta$ i $\alpha$ modifikaciją. Tai patvirtina didesnès bandiniu išsiplètimo reikšmès $(\sim 0,8) \%$ tu modelinių formavimo mišiniu, kuriu sudettyje buvo daugiau kvarco. Bandinių, paruoštu iš Kertupio-2 molio su langu stiklo laužo, mikrosilicio ir kreidos priedais, maksimalus išplètimas siekia apie $0,6 \%$.

Intensyviausiai visų bandinių susitraukimas vyksta $800-850^{\circ} \mathrm{C}$ ir apie $1000^{\circ} \mathrm{C}$ temperatūrose, taip pat beveik vienoda ir susitraukimo pradžios temperatūra $\sim 800^{\circ} \mathrm{C}$. Šie procesai susiję su karbonatų skilimu ir būdingi visiems karbonatiniams moliams. Pirmas susitraukimo etapas $800-850^{\circ} \mathrm{C}$ susijęs su molio mineralų skilimu.

Pereinant $i$ antraji susitraukimo etapa, nedideli bandinių susitraukimo greičio mažejjimą pastebime mišiniuose su glaukonito, Ukmergès molio ir mikrosilicio priedais $(3,5$ pav.).

Antrasis susitraukimo etapas yra susijęs su nauju kristalinių fazių susidarymu medžiagoje ir vyksta, kai temperatüra viršija $1000^{\circ} \mathrm{C}$. Mikrosilicio ir langy stiklo laužo priedai turejo didžiausios ittakos bandinių susitraukimui, kurio reikšmès

3 lentelè. Laboratorinių bandinių iš Kertupio-2 molio su ịvairiais priedais sukepimo rodikliai

Table 3. Baking data of laboratorial samples from Kertupis- 2 clay with various additives

\begin{tabular}{|c|c|c|c|c|c|c|c|c|c|c|}
\hline \multirow{3}{*}{$\begin{array}{l}\text { Ban- } \\
\text { dinio } \\
\text { Nr. }\end{array}$} & \multirow{3}{*}{$\begin{array}{l}\text { Bandi- } \\
\text { niụ } \\
\text { forma- } \\
\text { vimo } \\
\text { drègmé, } \\
\%\end{array}$} & \multicolumn{9}{|c|}{ Išdegimo temperatūra } \\
\hline & & \multicolumn{3}{|c|}{$1000^{\circ} \mathrm{C}$} & \multicolumn{3}{|c|}{$1030^{\circ} \mathrm{C}$} & \multicolumn{3}{|c|}{$1050^{\circ} \mathrm{C}$} \\
\hline & & $\begin{array}{l}\text { Degama- } \\
\text { sis susi- } \\
\text { traukimas, } \\
\%\end{array}$ & $\begin{array}{l}\text { Tankis, } \\
\mathrm{kg} / \mathrm{dm}^{3}\end{array}$ & $\begin{array}{l}\text { Vandens } \\
\text { imirkis, } \\
\%\end{array}$ & $\begin{array}{l}\text { Degama- } \\
\text { sis susi- } \\
\text { traukimas, } \\
\%\end{array}$ & $\begin{array}{l}\text { Tankis, } \\
\mathrm{kg} / \mathrm{dm}^{3}\end{array}$ & $\begin{array}{l}\text { Vandens } \\
\text { imirkis, } \\
\%\end{array}$ & $\begin{array}{l}\text { Degama- } \\
\text { sis susi- } \\
\text { traukimas, } \\
\%\end{array}$ & $\begin{array}{l}\text { Tankis, } \\
\mathrm{kg} / \mathrm{dm}^{3}\end{array}$ & $\begin{array}{l}\text { Van- } \\
\text { dens } \\
\text { imirkis, } \\
\%\end{array}$ \\
\hline 1 & 22,7 & 2,3 & 1,82 & 11,2 & 2,3 & 1,81 & 10,4 & 7,5 & 2,13 & 2,8 \\
\hline 2 & 24,6 & 1,2 & 1,84 & 13,7 & 1,3 & 1,84 & 12,1 & 1,3 & 1,85 & 10.5 \\
\hline 3 & 23,3 & 1,9 & 1,85 & 10,0 & 2,1 & 1,86 & 8,1 & 2,5 & 1,88 & 6,8 \\
\hline 4 & 25,1 & 2,5 & 1,87 & 10,3 & 2,5 & 1,89 & 7,5 & 2,6 & 1,96 & 6,0 \\
\hline 5 & 21,8 & 3,3 & 1,74 & 17,0 & - & - & 4,2 & 6,1 & 1,96 & 1,1 \\
\hline 6 & 18,6 & 3,7 & 1,65 & 16,9 & - & - & 1,2 & 6,2 & 1,94 & 0,9 \\
\hline 7 & 22,4 & 3,8 & 1,73 & 17,1 & 6,9 & 2,33 & 0,4 & 10,7 & 2,11 & 0,5 \\
\hline 8 & 23,6 & 1,8 & 1,79 & 11,9 & 1,9 & 1,77 & 10,9 & 3,5 & 1,89 & 6,2 \\
\hline
\end{tabular}




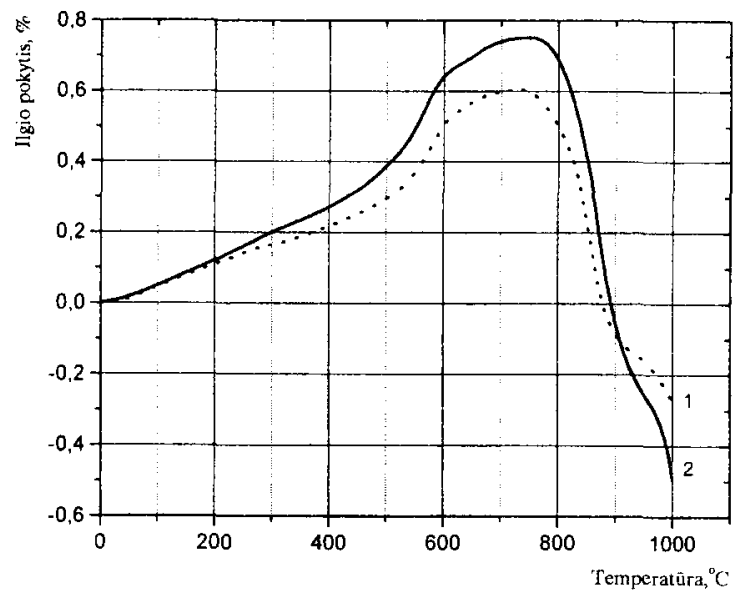

3 pav. Bandiniu Nr. 1-(1), Nr. 8-(2) dilatometrinès kreivès

Fig 3. Dilatometric curves of examples No 1-(1), No 8-(2)

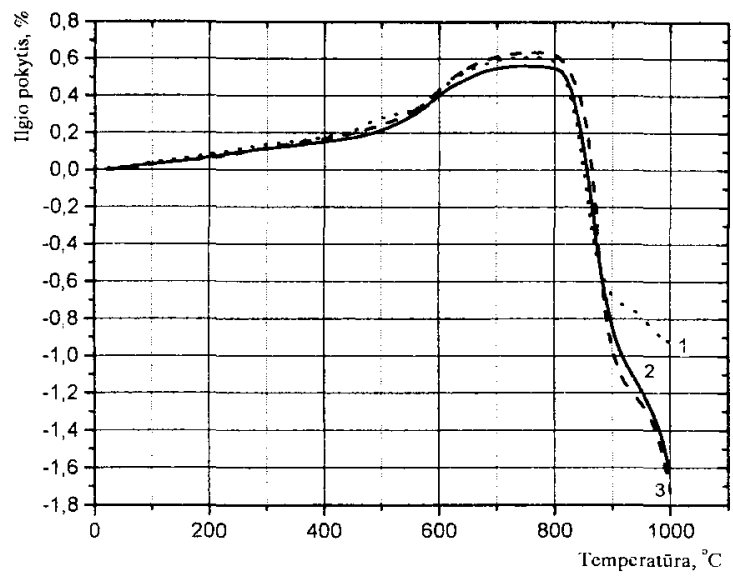

4 pav. Bandiniu Nr. 2-(1), Nr. 3-(2), Nr. 4-(3) dilatometrinès kreives

Fig 4. Dilatometric curves of examples No 2-(1), No 3-(2), No 4-(3)

atitinkamai keitesi $1,12-2,48 \%$ ir $1,11-1,21 \%$. Mažiau $(0,80-0,9 \%)$ susitraukè bandiniai su Ukmergès molio, glaukonito ir kreidos priedais.

Bandymu rezultatai gamybinèmis salygomis rodo, kad gaminių sukepimo lygi galima padidinti, esant didesniam stiklo laužo priedo kiekiui formavimo masèje. Laboratoriniais duomenimis, esant šam priedui, išdegtu bandinių Nr. 2, 3, 4 vandens įmirkis sumažejo iki $6 \%$ tik išdegant juos ne žemesnèje kaip $1050^{\circ} \mathrm{C}$ temperatūroje. Tam mažiau tinka Ukmergès molio ir glaukonito priedai. Mikrosilicis netinka, kadangi sumažina sukepimo intervalą, todèl bandiniai linkę deformuotis.

Išdegimui panaudojus mazuta, degimo dujose esantys sieros oksidai reaguoja su kalcio junginiais keraminès

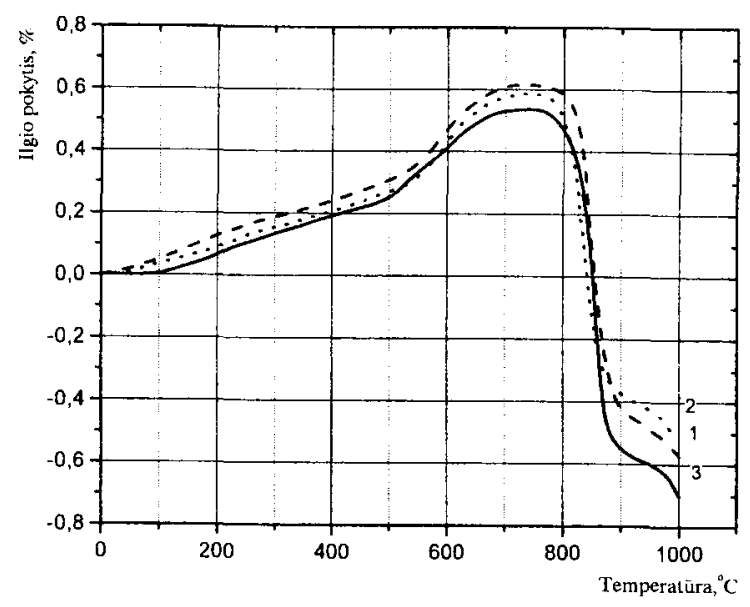

5 pav. Bandinių Nr. 5-(1), Nr. 6-(2), Nr. 7-(3) dilatometrinès kreives

Fig 5. Dilatometric curves of examples No 5-(1), No 6-(2), No 7-(3)

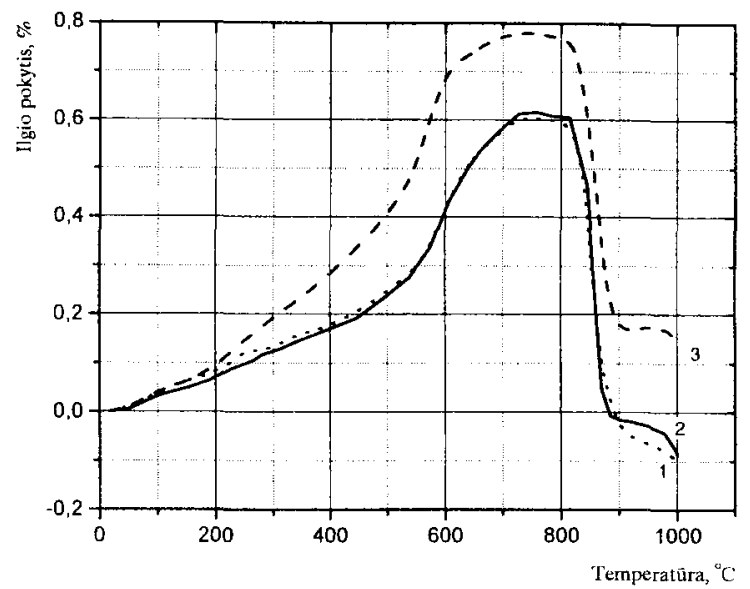

6 pav. Bandinių Nr. 9-(1), Nr. 10-(2) ir gamybinès masès - (3) dilatometrinès kreivès

Fig 6. Dilatometric curves of examples No 9--(1), No 10-(2) and experimental mass - (3)

Šukès paviršiuje - susidaro $\mathrm{CaSO}_{4}$ baltos nuosedos. Todèl 7 paveiksle pateiktoje rentgenogramoje išryškèja anhidritui charakteringos smailès $(0,349 ; 0,283 ; 0,233) \mathrm{nm}$ Cheminès analizès duomenimis, keraminès šukès paviršiniame sluoksnyje nustatytas sieros junginiu kiekis buvo $>2,0 \%$ (skaiciuojant pagal $\mathrm{SO}_{3}$ ), o viduriniuose sluoksniuose svyravo nuo 0,36 iki $0,66 \%$.

Šio nepageidaujamo reiškinio galima išvengti, jeigu klinkerinès keramikos gamybai bus naudojamas besieris mazutas. Remiantis 4 lenteleje pateiktais palyginamaisiais rezultatais, matyti, kad, deginant įvairių rūšių skystaji kura, sieros oksidu kiekis degimo dujose keičiasi nuo 5565 iki $315,3 \mathrm{mg} / \mathrm{m}^{3}$. 


\section{Išvados}

1. Parinkus sukepimą skatinančius priedus iš Lietuvos karbonatingu, lengvai besilydančių moliu, buvo gauti sukepusios keramikos dirbiniai, kuriu vandens imirkis $<6 \%$. Iš visų tirtų priedų žemiausioje temperatūroje prasideda sukepimo procesas, kaip prieda naudojant langu stiklo duženas.
2. Keramikos dirbinius išdegant sieringu mazutu, keraminès šukès paviršiuje susidare $>2,0 \%$ sieros junginiし, o viduriniuose sluoksniuose, kurie neturèjo salyčio su kuro degimo produktais, svyravo nuo 0,36 iki $0,66 \%$. Taikant magnezini sieros iš skystojo kuro pašalinimo bū$\mathrm{da}$, iš mazuto degimo duju siera pašalinta iki $\mathrm{SO}_{2}$ koncentracijos $315,3 \mathrm{mg} / \mathrm{m}^{3}$. Tai rodo, kad apdailos keramikos gamyboje gamtines dujas galima pakeisti $i$ daug pigesni kurą-mazutą.

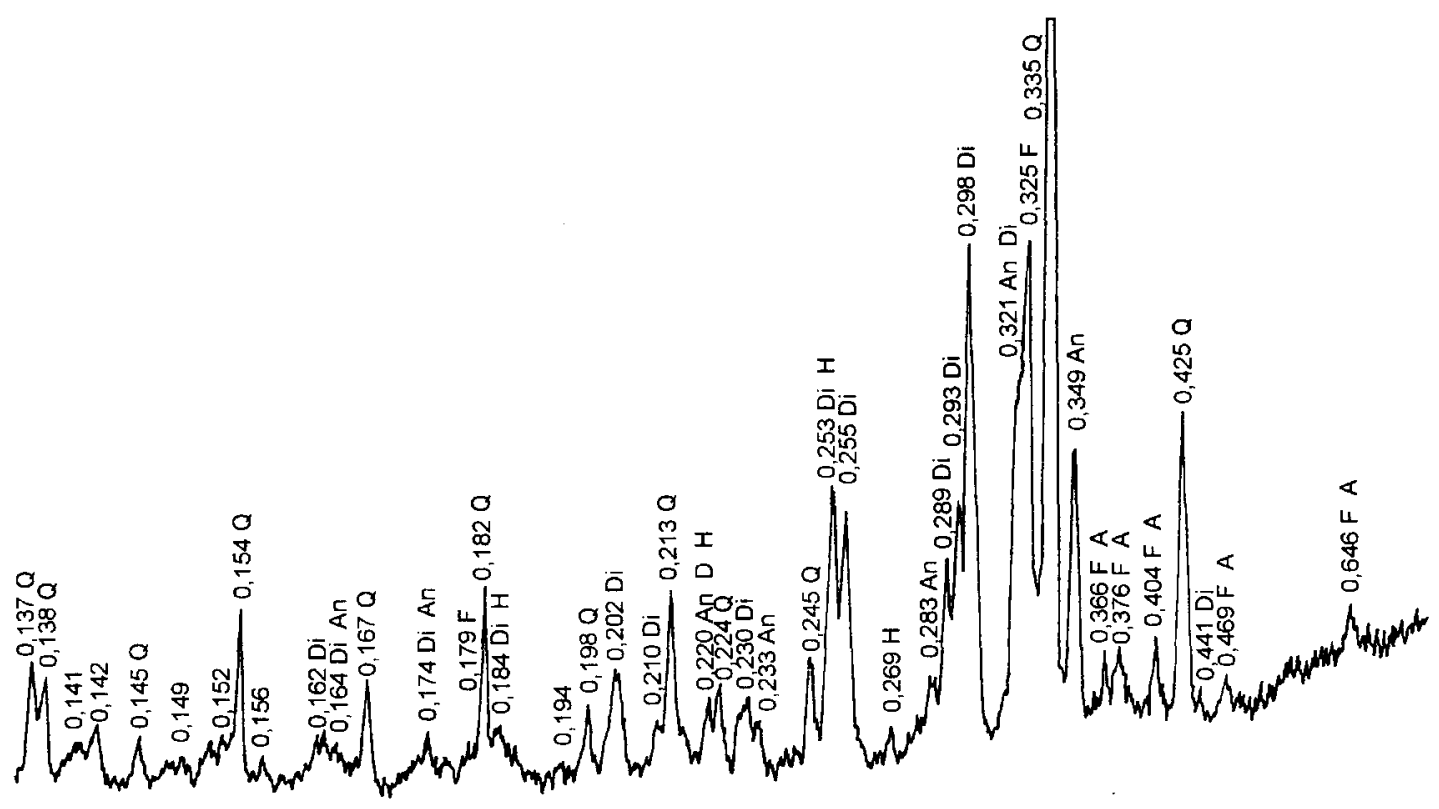

7 pav. Keraminès šukès paviršinio sluoksnio rentgenograma (nm)

Fig 7. XRD pattern (nm) on the surface layer of ceramic splinter

4 lentelè. Palyginamieji duomenys deginant orimulsiją, mazutą M100 ir besierị mazutą

Table 4. Comparable data of burning orimulsion, mazout M100 and desulphurised mazout

\begin{tabular}{|l|l|l|l|l|}
\hline \multirow{2}{*}{ Parametrai } & \multicolumn{2}{c|}{ Orimulsija } & Mazutas M100 & Besieris mazutas \\
\cline { 2 - 5 } & \multicolumn{3}{c|}{ Matavimo salygos } \\
\hline & pries filtra & po filtro & po filtro & be filtro \\
\hline Vidutinis srauto greitis, $\mathrm{m} / \mathrm{s}$ & 17,492 & 8,8817 & 8,8817 & 9,7 \\
\hline Ortakio plotas, $\mathrm{m}^{2}$ & 12,254 & 24,0 & 24,0 & 1,13 \\
\hline S̆lapių dujų srautas ortakyje, $\mathrm{m}^{3} / \mathrm{s}$ & 214,348 & 213,161 & 213,161 & 10,19 \\
\hline Šlapių dujų srautas normaliosiomis salygomis, $\mathrm{m}^{3} / \mathrm{s}$ & 129,542 & 129,261 & 129,261 & 6,9 \\
\hline Sausujų dujų srautas normaliosiomis sąlygomis, $\mathrm{m}^{3} / \mathrm{s}$ & 121,201 & 120,143 & 120,143 & 6,1 \\
\hline Dulkių koncentracija, $\mathrm{g} / \mathrm{m}^{3}$ & 0,19198 & $0,00510^{*}$ & - & 0,0063 \\
\hline $\mathrm{Dulkių} \mathrm{išmetimas,} \mathrm{g} / \mathrm{s}^{*}$ & 23,2678 & 0,61273 & - & 0,043 \\
\hline $\mathrm{SO}_{2}$ koncentracija, $\mathrm{mg} / \mathrm{m}^{3}$ & 5565 & 5550 & 5123 & 315,3 \\
\hline $\mathrm{NO}_{\mathrm{x}}$ koncentracija, $\mathrm{mg} / \mathrm{m}^{3}$ & 302 & 313 & 90,6 & 187,3 \\
\hline $\mathrm{CO}_{2}$ koncentracija, $\%$ & 907 & 9,8 & - & 1,78 \\
\hline
\end{tabular}

* Elektrostatinio filtro efektyvumas $97,36 \%$ 


\section{Literatũra}

1. A. Sadūnas. Aliumosilikatinių dirbiniı ilgaamžiškumas. Vilnius: VPU leidykla, 1997. $234 \mathrm{p}$.

2. A. Sveikauskaite. Kvarteriniuose ir devoniniuose aliumosilikatuose vykstanciu reakciju intensyvinimo tyrimas. Dakt. dis. santrauka. Vilnius, 1997. 20 p.

3. Hanawalt Search Manual. Inorganic Phases. Sets 1-48. Pensylvania, JCPDS, 1998

4. А. И. Августиник. Керамика. Л.: Стройиздат, 1975. 73 с.

5. Т. Шарло. Методы аналитической химии. В 2-х частях. Ч. 2. Количественньй анализ неорганических соединений. М.: Химия, 1969, с. 988-989.

6. ГОСТ 10585-75 Мазут. Москва: Изд-во стандартов, $1982.7 \mathrm{c}$.

7. A. Kaminskas, G. Smolianskienè, B. Valužienè. Peculiarities of dissulphurating of mazout by magnesium oxide // 3 rd National Lithuanian conf. „Chemija-97“. Vilnius, 1997. $26 \mathrm{p}$.

8. B. Valužienè, A. Kaminskas, G. Kiesus ir kt. Lietuvos Respublikos patentas Nr. 4354 „Skysto kuro nusierinimo būdas“ / Lietuvos Respublikos patentų registras, 1998.

Iteikta 19990317

INFLUENCE OF ADDITIVES AND SULPHUROUS MAZOUT ON THE QUALITY OF CARBONACEOUS CLINKERY CERAMIC SPLINTER

\section{A. Kaminskas, G. Smolianskienè, Č. Valiukevičius}

\section{Su m mary}

The Republic of Lithuania does not possess a standard document on clinker bricks. In the standard LST 1458 clinkery and baked bricks are defined as products with water absorption lower than $6 \%$ and $5 \%$, respectively.

Lately in the world market the prices of oil and its products have been greatly reduced. Since the production of clinkery bricks consumes much more fuel than baking building bricks, it would be more economic to use mazout instead of natural gas.

Mazout comprises sulphur (2.5-3.5) \%, therefore on the surface of produced clinkery bricks appear there sulphatic spots, worsening the surface of products.

In this study the possibilities were researched how to get clinkery ceramics from carbonaceous $[\mathrm{CaO}+\mathrm{MgO}=(12.01-$ $14.73) \%$ ] easily dissolved clay of Kertupis-2 quarry, selecting additives which stimulate baking and to determine the influence of sulphurous mazout on the properties of ceramic splinter.

Chemical composition of Kertupis-2 clay is presented in Table 1. Mineralogical composition (Fig 1) of this clay was investigated by radiographic method and dry remnant of water extract was evaporated (Fig 2). $\mathrm{CaCO}_{3}$ predominated in the dry remnant. Forming mixtures, composition of which is given in Table 2, were prepared. While investigating deformation changes of forming mass at the moment of baking, dilatometric research was carried out (Fig 3-6). Baking data of laboratorial samples from Kertupis-2 clay with various additives are presented in Table 3 depending upon baking temperature. Measurings of dust amount and gas emission into atmosphere were performed when buming orimulsion, mazout M100 and desulphurized mazout with the additive of magnesium oxide. Comparable data are presented in Table 4. Sulphur oxides present in combustion gas react with calcium combinations on the surface of ceramic splinter, resulting in white deposit of $\mathrm{CaSO}_{4}$. RDX pattern presented in Fig 7 has characteristic elements of anhidrite $(0.349 ; 0.283 ; 0.233) \mathrm{nm}$. Having carried out the chemical analysis on the surface layer of ceramic splinter, the determined amount of sulphur combinations was more than $2.0 \%$ (rating according to $\mathrm{SO}_{3}$ ). In the middle layers its amount fluctuated from 0.36 to $0.66 \%$

Having summarized the results of research the following conclusions have been drawn

1. Choosing additives stimulating baking, baked earthenware with water absorption less than $6 \%$ from Lithuanian carbonaceous easily dissolved clays were obtained. When breakage of window-pane was used as an additive, baking process began at the lowest temperature.

2. Baking earthenware with sulphury mazout, $>2.0 \%$ of sulphur combinations formed on the surface of ceramic splinter, and in the middle layers, which had not any contact with fuel burning products, its amount fluctuated from 0.36 up to $0.66 \%$.

Applying magnesium oxide desulphurisation way, it is possible to desulphurise burning gas of mazout up to 315.3 $\mathrm{mg} / \mathrm{m}^{3}$ of $\mathrm{SO}_{2}$ concentration. The research has developed the possibility for ceramic industry to change natural gas into much cheaper fuel - mazout.

Antanas KAMINSKAS. Doctor Habil, Professor. Director of Physical and Chemical Research Centre, the Institute of Thermoinsulation, Linkmenų 28, 2600 Vilnius, Lithuania

President of Lithuanian Chemists' Society. Author of 68 investigations, 3 patents and monographs. At present the working group chief for reorganisation of building materials industry. Research interests: complex processing and use of dolomite.

Gražina SMOLIANSKIENE. Doctor. Vilnius Gediminas Technical University, Sauletekio al. 11, 2040 Vilnius, Lithuania.

A graduate of Vilnius University (1991). Doctoral student of VGTU since 1994. Scientific probation at J. Nofer Institute of Occupational Medicine (Poland) (1998). Co-author of 11 scientific publications. Research interests: building materials, physical-chemical investigation methods

Česlovas VALIUKEVIČIUS. Doctor, Senior Researcher. Institute of Thermoinsulation, Linkmeny 28, 2600 Vilnius, Lithuania.

A graduate of Vilnius University (1965). Doctor (1972). Author of about 53 scientific publications, co-author of 11 inventions. Research interests: durability and production technology of building ceramics. 